\title{
COPING STRATEGIES OF CHILDREN FROM DIVORCED FAMILIES IN NORTH-WESTERN ETHIOPIA
}

\author{
NEGA GEDEFAW AGMASE* \\ School of Sociology and Social Work, Department of Criminology and Criminal Justice, College of Social Science and the Humanities, \\ University of Gondar, Ethiopia. Email: negagedefaw@gmail.com
}

Received: 08 February 2021, Revised and Accepted: 24 February 2021

\section{ABSTRACT}

Objective: Since children from divorced families suffered from multi-dimensional effects of divorce and those children are more likely to be involved in different income generating activities. This study attempted to investigate the coping strategies of children from divorced families in North-Western Ethiopia.

Methods: The qualitative, specifically phenomenological research design was employed for understanding the lived experiences of children from divorced families. The data were collected from children of a divorced family and experts through in-depth interviews, focus group discussion, and key informant interviews. Then, participants of the study were selected using the snowball sampling technique. As well, the collected data analyzed and interpreted thematically to address the aforementioned objective of the study.

Results: The findings of the study reveal that children from divorced families developed a wide range of survival strategies within the face of challenges and difficulties that support their life on their own such as petty business, Shoeshine, labor activities, delinquent activities, and begging.

Conclusion: The study concluded that the problem of divorce needs appropriate attention from governmental and non-governmental organizations as well as social institutions akin to family and religion.

Keywords: Coping strategies, Children, Divorced families, Ethiopia.

(C) 2021 The Authors. Published by Innovare Academic Sciences Pvt Ltd. This is an open access article under the CC BY license (http://creativecommons.org/ licenses/by/4.0/) DOI: http://dx.doi.org/10.22159/ijss.2021v9i2.41038. Journal homepage: https://innovareacademics.in/journals/index.php/ijss

\section{INTRODUCTION}

Divorce is a separation of two people that shared a life together [1] Moreover, it can be a spontaneous event during a family's life since it is something that affects each member of a family at different times and in several ways. Hence, about half of all marriages will end in divorce and it dispatches a million children annually to affect the process of divorce [2]. Each year, many children around the globe face family disruption, and in many countries, divorce rates are rising [3]. Similarly, research conducted by Larsen [4] documented that $45 \%$ of first marriages in Ethiopia ended up in divorce within 30 years of the formation of marriage, and two-thirds of the ladies who prefer to get a divorce do so within the primary 5 years of their marriage. Actually, practicing this amount of divorce rate within the Ethiopian context is very alarming.

Children experience divorce deeply and personally, and thus the potential for negative short- and long-term consequences is considerably higher for children whose parents divorced than for those from non-divorced families [5]. They are also suffered from multi-dimensional effects; those children are more likely to be less educated, experience poverty or socioeconomic disadvantage, and develop anti-social behavior, to be engaged in promiscuous (having many sexual partners), violence, crimes, and other related anti-social and criminal activities [6], and will including other behavioral problems such as drug and/or alcoholic addictions, marriage, or cohabitation at an earlier age, resulting to point out high for separation or divorce [7]. In Ethiopia, around 6,042,357 children are expected to live under difficult conditions due to families' inability to support children because of family dissolution [8]. Studies are conducted in Ethiopia that focused on the issue of divorce from different vantage points. For instance, Abebe [9], Aster [10], and Seid and Yemataw [11,12], conducted research regarding divorce. However, most research as indicated is based on the causes of divorce. Relatively little is concerned with the effects of divorce on children's wellbeing and even less in seeking to concern with the coping strategies of children from divorced families. Moreover, the majority of the above research's done related to the issue is conducted usually using either mixed or quantitative dominant methods than purely qualitative methods. Therefore, this study attempted to fill the knowledge gap by studying the coping strategies employed by children from divorced families, and research design as well as data collection methods gap by employed a phenomenological design of qualitative research approach and best qualitative data collection methods such as key informant interviews, focus group discussion (FGD), and in-depth interview.

\section{Study objective}

The objective of the study is to investigate the coping strategies of children from divorced families in North-western Ethiopia.

\section{METHODS AND PROCEDURES}

In this section, the overall processes and procedures that were employed in this study including a description of the research approach and study design, data collection methods, method of data analysis, and ethical considerations are discussed in detail.

\section{Study design and approach}

The study was conducted in North-Western Ethiopia. The investigator of this study employed a qualitative research approach for the reason that its usefulness broadens and deepens our understanding of how things came to be the way they are in our social world. The qualitative research method also provides rich data about the real life of children from divorced families and their living situations because it seeks to answer questions framed with what and how of a given phenomenon. Along with the qualitative approach was follow a phenomenological design in that it has given great emphasis to the lived experience of children 
from divorced families. The assumption to select this research design is that in phenomenology the researcher describes the lived experiences of children's about a phenomenon as described by them and/or the researcher relies on the participants' own perspectives to provide insight into their motivations. Furthermore, using such a design, study participants were selected since they need to live and/or experienced the issue and/or difficulty being studied within the study area. Consequently, how those informants add up of their experience was examined which, in turn, was recognized through the method of interpretation.

\section{Data collection methods}

Based on the objectives of the study, the most important data collection methods that are relevant to qualitative research were employed. In doing research using multiple data collection strategies are more advantageous than a single type of data collection method because triangulating different strategies give opportunities to compensating for weaknesses of one data collection method by the strength of the other. For this, in-depth interviews, FGD, and key informant interviews were employed since these methods enable the researcher to assure the validity of the study. Let see the brief description of each data collection methods as follows.

\section{In-depth interview}

For this study, in-depth the interview was conducted with children's from divorced families and the size of the interviewee was 17 as it was decided based on data saturation. The ground for the choice of this type of data collection method is that; it enables the researcher to collect more data that may not have been possible through any other means. As well, this interview provided an opportunity for the researcher to get detailed information about the coping strategies of children from divorced families. Snowball the technique was in use to select children for an in-depth interview in a way that allows producing qualitative data on the experience of children from divorced families.

\section{FGD}

For this study, FGD was conducted to collect primary data from children of divorced families. The rationale for the choice of this data collection method is that; it is one of the most important ways to generate a rich understanding of children's experiences and beliefs as well as it may also be used to access the views of minority or disadvantaged groups, such as women, children, or people with disabilities [13]. The number of participants in a single group for this study was 8 and the justification of this size of participants is that fewer people are best and the ideal size of a focus group is usually between six and eight participants [14]. Although it is recommended that conducting FGD with two to three groups for a small project or small study, it was conducted from two groups with eight discussants in a good setting by arranging with them based on their willingness. Thus, it was started by briefing FGD participants on the purpose of the research and they were encouraged to take part in the discussion and speak their views freely.

\section{Key informants interview}

Key informant interviews were also employed to gather information about the issue from a person's unique professional background related to the issue since it enables the researcher to obtain vital information about the coping strategies from divorced families. It was conducted by experts of the office of women and children's affairs, court judges, project of justice for children, solicitors, and the prosecutor of Justice Office through interviewing them, and based on this the size of key informants was five. Consequently, the method was to help to gather in-depth information on the practical experiences and efforts are done by the concerned bodies toward the coping strategies of children from divorced families.

\section{Data analysis procedure}

The data that were gathered from different sources using different data collection methods have been analyzed and interpreted thematically. Before analysis, it was prepared, transcribed, and translated to English as well as thematically coded since the data were collected in the Amharic language. For the reason that in phenomenological research the findings described from the subject's point of view, the researcher identifies themes and the structural explanation of findings is developed [15].

\section{Ethical considerations}

In doing research, human subjects must be treated with dignity, fairness, and respect. Besides, social research should never harm the people being studied, regardless of whether they volunteer for the study or not. Research ethics involves the protection of the dignity of subjects and the first and foremost responsibility of the researcher is avoiding harm as well as doing well for the well-being of participants of the research [16]. Therefore, ethics issues were a high concern in this study, during the time of field entry, data collection, analysis, and interpretation of results. First of all permission and/or all ethical clearance were obtained from the concerned ethical clearance office of the University of Gondar as needed. Hereof, the purpose of the study and the manner in which the data were handled was explained to the actors that were directly or indirectly concerned and/or involved with the issue under the study. During the individual interviews, the researcher has been given time to the children to talk about their feelings and perceptions. As a result, the required data were collected based on the informed consent of the participants of the study.

\section{RESULTS}

This part presents the major findings of the study. The study sought to identify the coping strategies of children from divorced families in NorthWestern Ethiopia. As the collected data indicated that children from divorced parents and/or families used a mixture of strategies to cope up with problems, difficulties, and challenges, they were facing to survive their life due to their parents' divorce such as petty business, shoeshine, child labor, delinquent activities, and begging. Since, coping strategies are used by children from divorced families to encounter their difficult life which means obtaining food, clothes, and shelter, and health care services but it depends on the personal strength, age, and sex of the child.

\section{Shoeshine}

It was revealed that children from divorced families sought to engage in shoeshine especially boys to survive their life from their own. For most children's engaging to be a shoeshine boy is one of the easiest incomegenerating strategies to survive their life. However, some of them are not staying longer on this job because there are days they passed without earn enough money for their daily expenditures. Regarding this a 17 years, an old child from a divorced family described his survival strategies as:

I was raised with my mother after my parents were divorced but after some time my stepfather refused to raise me. And it got me out of the home so that I started living on the street. When I lived on the street, I didn't have anything I could take care of myself, thus I started working shoeshine with my friends, and my friends helped me to get better, and after a while, I started working independently. But I have a lot of problems when I do this kind of work because the income I get from the job is not enough to lead my life properly. There is a customer loses Sometimes because as you see there are many children's who work shoeshine in the city. And it is difficult to earn enough money for food, clothing, and to pay rent; there is no one who can help me, including my family, but I work hard with God.

It can be understood from the above evidence that children from divorced parents are often at greater risk of being evicted and that they are more likely to engage in different income-generating activities and shoeshine is one among them. Since shoeshine is probably the only chance, they can get when they see it in terms of other options. Even if these children do this job, they may not be able to earn enough money to lead their lives well nonetheless; shoeshine is one of the main modes of running their lives.

Anymore 12-year-old shoeshine boy explained how he making money by involving shoeshine as follows:

Before my parents' divorce, I had a smart life but after the divorce, I suffering and passed through difficult conditions because I was a kid and unable to get a job. While some years later I do shoeshine and 
sometimes I strip crow to counter vial. Even so, I doing such activity the money I obtain is insufficient for food, clothes, and shelter as well as due to this I passed the night on the veranda. The problem I faced in the veranda is you know the older streets bulldoze by dagger and snatch my money and it makes me crazy.

As we can see from the excerpt above, even though children from divorced families have the opportunity to help themselves, by engaging in shoeshine that the money they earn at the bottom is not enough and they will do more work to compensate for it. However, the unsafe work environment of these children puts them at greater risk for further harm. For example, the money these children earned while suffering from cold and helmet means that the money will be used by other people.

To boost, FGD participants reported it as:

Most of us work in shoeshine and lead our lives. If that does not have any of us working, we will be sharing. But there is no convenient working environment, and sometimes there is a chance that we will not be able to operate because there are many shoeshine boys and there are many days where we do not have enough money.

In addition, one of the key informants explained how children from divorced families involved in this income-generating activity support their life as:

Most of the time, children from divorced families, especially the most underprivileged children, use shoeshine as a prime option to lead their lives on their own and meet their basic needs. And these children can do the work of cleaning this shoe on the streets and around the gate of public or non-governmental organizations or hotels. But these children do this because they are forced to lead their lives from their own, as they have lost their families and have no one to help them else.

The data above reveal that as the complexity of the ancestors' issue increases, children from divorced families are more likely to seek solutions to their harms and challenges on the street. Children, especially at the younger age who live without at least one of their parents or who do not have a caretaker and live on the street full-time, are engaged as a shoeshine to meet their own survival needs because there is nobody else to secure those needs such as food, clothes, and so on.

\section{Petty business}

The study opens that children from divorced families did not stick in one activity for a long time but they shift here and there and doing several things within a short period of time. They shift from one activity to another, however, depending on the amount of pay and security available and the restrictions placed on their social interactions. They were involved in selling mobile cards, sweets, water, and other items especially along the road, at the bus terminal, and around hotels. Vis-àvis a 12-year-old child from a divorced family described it as:

Because my parents are divorced and my mother is poor, it is very hard to stay at home. So I often shop around the city and sell mobile cards, biscuits, and other stocks around bars, cafes, and hotels. In fact, I get food after I have bought my stocks for enough money. Sometimes if I don't make enough money I go out with friends and eat a leftover and I even do it on the porch. Occasionally, when some individuals give me money for tea, I go to the movie theater for the money I have left from food.

From the information provided, it is clear that the children from divorced families run small businesses to win their living. The data show that these children, although maybe busy with this work, the money may not have enough to meet their basic needs. Moreover, because of their financial constraints, they eat the hotel's tropical food, and there are some individuals who try to help them with giving bread money.

Any more a 13-year-old children from divorced families explained it as follows:

I am learning and I doing a small business to support my education and my life because when my parents have got a divorce I was left with my mother. But she is poor I mean her livelihood is selling beer and weed and she sickens sometimes, however; her income is insufficient for us (for me and Mom) to survive. So I support my education and home expenditure by selling gum, soft, biscuit, and mobile card. My job is not yet secured I mean at night there is a good job, I scrolling at night clubs and I sell a lot including condoms and cigarettes however my money is taken away from me by thefts and older streets. And I betake return to the home early as a solution.

We learn from the story above those children from divorced families are forced to assume different responsibilities without having to sell different goods. For example, they can afford educational materials, buy clothes, and even help their family with the money, they make from the sale. However, what is still a concern and a problem for all children is that the job of the children is at stake. Since they have worked with so many hardship environments that they have stolen the money by the thieves and bullies have stolen.

As well, a 14-year-old child from divorced parents described the way he earns money by engaging in petty business as:

My parents have got divorced 5 years ago and as I remember the process I mean it was full of conflict. I just take money from my mother and start a petty business such as selling water, soft drinks, gum, cookies, and so on around the stage and roads with my friends. The income is good but I can't able to attend my education because I am children of the poor and there is nobody else to support me and my mother. And I should work hard a full day to support myself as well as my mother sometimes.

As can see from the finding above, small businesses are still the norm for many children, but they need to work hard and work full-time because they need enough money to lead their lives and help their families now and then. As a result, they are forced to give up and sacrifice their education which is necessary for their future lives.

FGD discussants also indicated it as:

Petty business (selling water, soft drinks, gum, and biscuit, mobile card and so on) is one of our major jobs in order to fulfill basic needs more than ever food and cloth by our own effort. Because the majority of our parents didn't care about us and we are not yet getting any financial support from others.

Again, it can be understood from the group discussion that the children from divorced families who are engaging in petty businesses are covering the cost of their daily consumptions and clothes from their own. This is because no one can meet their needs, including food and clothing either their family or any other people or concerned body unless they are covered from their own.

As well, the above findings also supported by the finding gathered from a key informant interview as:

Petty business is one of the dominant income-generating and selfsupporting mechanisms employed by children from divorced families to survive their life. And there are some children's who are trying to support their families, especially who are left with their mothers by doing such kind of activities. As well; the wondering thing here is there are people who try to support these children by buying stocks and goods from them.

Hence, as it was revealed that children from divorced families are more likely to be engaged in petty business to sustain themselves and some of them are trying to support their families. Children's engagement in income-generating activities is primarily motivated by family breakdown and or parents' divorce as well as economic hardship. Thus, these children have to feed themselves and support their parents by buying home expenditures from their profit sometimes by engaging in petty businesses.

\section{Labor activities}

Child labor is one of the most dominant income-generating activities employed by children from divorced families. Children from broken 
families are living without family or caretakers or at least they lost one of their parents and because of this, they are forced to engage in child labor and or street labor to meet their own needs. Hence, these children involved as an assistant in trade and commerce activities, forced labor activities, activities in agricultural labor, domestic activities as well; they are forced to involve in criminal activities. Regarding this 17 years, the old child explained it as:

I was a houseman and doing many activities such as keeping animals, cleaning animals' waste from the house, and so on. Oh, it was difficult I mean keeping cows during the rainy season including early in the morning with the presence of chilly weather. Due to this I am forced to change my job and joined street labour. Now I am caring goods around the market and stage as well; I am doing as a messenger from super-markets and marts. But the money I get is insufficient for food, clothes and other consumptions and nobody is around to support me including my parents.

It can be understood from the quote above that the children from divorced families are employed as caretakers of the home of the people to manage themselves and maintain their lives. By the way, these children are more likely to suffer when they do this kind of work because they do not have the ability to cope with the pain.

As well, FGD participants described in their engagement of different labor activities to survive as:

We are engaged in different labour activities such as carrying stocks for supper markets, a box of beer and soft drinks for restaurants, carrying different goods from the market what is called a knot, and sometimes we are engaged in the car and Bajaj washing in order to get money for food and other consumptions.

To boost, one key informant explained it as:

Children from divorced families are more exposed to engage in different labour activities to support their life from their own. Some of them may be employed as a cowherd, a strip of firewood, and muck, as well as they, may be forced to perform domestic activities such as child caring, home cleaner, and washing. While others involved in different labour activities along the street, market, and even in private organizations. Shockingly there are individuals who used children from divorced families in harmful criminal activities especially for theft and used them to gather alms as well; they forced them to involve different harmful labour activities illegally.

As can be understood from group discussion and key informant interview above, engaged in different labor activities is one major survival strategy of children from divorced families. They involved in labor activities that are hazardous for them and likely interfere with their education or be harmful to a child's health or physical and social development. It is advisable that involving children in light activities in the home helps develop the child, they learn how to be responsible, they become healthy and fit, learn how to take on various roles, and become dependable grow up to responsible persons. However, involving them in activities that deprive them of their rights and not paid a payment, they deserve for their job should be fought against. Consequently, child labor affects children from divorced families in different ways such as it condemns the child to a life of unskilled and badly paid work.

\section{Begging}

Even if it is not reported by children from divorced families during the in-depth interviews and FGD, the data from key informant interviews indicated that begging is another dominant survival strategy of children from divorced families. Especially, those who are living without their families or those who do not have a caretaker and live on the street full time or part-time are engaged in street begging to feed them and fulfill their basic needs from their have. As regards, interview with one key informant explained how much children from divorced families engaged in begging to survive their life as:

Begging is one of the major ways of income-generating activity employed by children from broken families. Not all children from divorced families who are working or involved in different activities earn enough amount of money to get their food and so on. Thus, many of them dropouts from their job due to unable to cover their costs and unable to survive and cop up the hardship of works since they are a kid; they shift to and taken in to be considered begging as their ultimate alternative for their survival.

As it was revealed that, financial issues were one of the greatest sources of stress in children from divorced families since most of their parents go from a two-income household to two one-income households on the same income level. Dividing financial obligations and assets and determining child and spousal support can create significant tension between both parents. Due to this, they (parents) are unable to cover the necessary and sufficient costs of their children so that children from divorced families are more likely to engage in begging to collect money for the purpose of feed themselves and lead their life as well.

\section{Delinquent activities}

Children from broken families are usually engaged in different delinquent activities than children from intact families. In fact, the in-depth interview participants were not willing enough to explain whether they are involved in different delinquent activities or not. However, during key informant interviews, it was revealed well and FGD discussants explain it somewhat. Moreover, the reported delinquent activities in which children from a divorced family are involved to survive their life were theft, gambling, and so on. Regarding this one key informant reported it as:

Children need a parent or close caregiver who can control what they can do and cannot do as well as what is right and what is wrong. Therefore, divorced parents are less likely to have close parental supervision for their children because parents are more focused on their new marriages, and after the divorce, they are less likely to have their children financially. Thus, these wise children are drawn to a variety of myths and unacceptable activities in society, rather than doing different tasks to lead their own lives. For example, they engage in various types of theft, particularly pocket break-in, present at different gambling sites, and they are exploited in a variety of places, such as smoking, chat chewing, and drug abuse, to forget the social, economic, and psychological harm caused by their parent's divorce. And because the majorities of these children live on the streets and do not receive the love and care of their parents, they are forced to perform various mythical actions, and in the end, they are unlucky to be successful and smart in their last part.

More to the point, even though it is not reported by in-depth interview participants, the FGD discussants explained how much they are involved in different delinquent activities as a survival strategy as follows:

As we know, we children from divorced families do not have enough acceptance in society, and people just treat us as if we have no parents. Neither of our parents would give us financial support for food, clothing, and shelter. As a result, some children may fail to relieve hunger, so they steal and there are those who try to manage themselves by playing gambling. But despite the money available enough, policemen also beat us and our parents' divorce hurts us a lot.

Therefore, children from divorced families are usually forced to engage in delinquent activities such as they involved theft crime along with the road and bus terminals, and around the market to earn money for the purpose of fulfilling their basic needs particularly to feed themselves. Some of them also involved in gambling since they think it as they do not have other alternatives because they cannot get their parents and or families financial support as well; even they do not have a close attachment with other persons who can advise what to do and what not to do. Thus, these children are more vulnerable to different risks and problems than children from intact families as they are involved in risky, unhealthy, and delinquent or criminal activities to survive their life on their own.

\section{DISCUSSION AND CONCLUSION}

The results show that the age of the child at the time of the divorce does not determine the amount of difficulty they will have maintaining their 
life every so often. So as to means, they show that they are obtaining food, clothes, as well as shelter and health care services sometimes from their own by performing different income-generating activities. In safe and sound to this finding, the research conducted by Ebenezer [16] on uncovered coping strategies of children for survival of their own life revealed that they are involved in selling different sweets, water, juice, ice cream, and so on along the road and bus terminals. The finding of this study is as good as Ebenezer's finding that children from divorced families were involved in petty business and related activities as a survival mechanism such as selling gum, biscuit, juice, water, mobile card, and so on. They also survive their life by selling pants, socks, Pokémon, and other small stocks.

The finding of this study was revealed that parental divorced children worked daily along the market to carry knots, forced labor activities, and so on. Inconsistent with this Ebenezer also investigated it as they are worked daily along the shores sorting, drying, and packing sardines in sacks and others help to boil salt, digging limestone's, and fishing. While others involved in shoeshine for the purpose of money attainment to feed them and support their education and families sometimes, this finding is yet neither supported nor opposed by any scholars finding as far as the knowledge of the investigator of this research. In fact, because many children from divorced families live on the street, they may have to do many dangerous and unhealthy jobs and activities for the survival of their life. They are forced to do the unpaid job or they earn below what they deserve because they are a child without caregiver and custodian and the exploiters exploit them using children's boyhood.

As it was also stripped in the finding of this study, there are children from divorced families who survived their life involving on the street begging. In trustworthiness to this, a research conducted by Gemeda [16] on the cause, consequences, and coping strategies of streets in Shashemene Town, Ethiopia revealed that begging is one of the ways in which children live on the street applied to fulfill their basic needs. According to him, children engage in begging either full-time or part-time as a way of livelihood or supplementing their income from begging with that from other activities. Thus, the researcher of this study is aware that children from divorced families involved in begging on the street either full-time to meet their basic needs such as to feed themselves and buy clothes as well as beg their part-time to support their income-generating activities, and support their families may be. Moreover, in reverse to Gemeda's finding sometimes, they are forced by others to involve in begging for the purpose of alms and the offertory.

As well, children from divorced families employed different delinquent activities for the survival of their life. In reliable to this Akhtar [17] indicated that some adolescence engages them-self in risk-taking activities such as alcohol, sex, and criminal gang joining. As it was revealed, during key informant interviews and FGD children from divorced families are more likely to involve in delinquent activities such as theft, drudge use, and gambling to use it as a survival mechanism due to lack of finance to fulfill their basic needs except for sex. In similar to this, Parks [18] investigated that the family structure has a great impact on children involved in different criminal activities given that children from divorced homes have higher rates of delinquency compared to children from intact families, with the exception of alcohol use. In addition, but not similar with the above scholars finding in some cases indicated that children from divorced families are forced by others to be involved in different criminal activities especially in theft crime.
So then, divorce is multidimensional and it involves multifactor social events. Basically, it occurs easily within more open and urban areas and usually, it is affecting negatively the social and economic wellbeing of children and others. It is emerging as a form of new sociological events due to the pattern of sociocultural changes by the process of modernization and simultaneously urbanization since it occurs more in urban areas. As a consequence, children from divorced families are forced to employ different income-generating activities and survival mechanisms such as begging, child labor, and petty business, and so on to fulfill their basic needs from their own and support their education as well as their families sometimes. Thus, children are more likely to be the victim of the negative effects of divorce and they experience difficulties as well; they develop anti-social behaviors and more likely to involve in delinquent activities than children from intact families due to a lack of financial and social supports. In general, the researcher of this study feels that it can be concluded as: The effect of divorce is diverse and it is found in each community in Ethiopia, in which marriage is taken for life or it is for after death. Therefore, divorce is not culturally and socially accepted in almost all parts of Ethiopia but many people are widely involved now a day.

\section{REFERENCES}

1. Amato PR. Divorce in Europe and the United States. J Family Sci 2010;13:2-13

2. Westberg H. Children's Experience of Parental Divorce Disclosure: A Look at Intrafamiliar Differences, All Graduate Theses and Dissertations; 2000. p. 2677. Available from: https://www.digitalcommons.usu.edu/ etd $/ 2677$.

3. Larsen DT. Divorce in Ethiopia. J Biosoc Sci 2000;32:255-272.

4. Martin PS. Expressed attitudes of adolescents toward marriage and family life. J Marriage Family 2003;38:359-67.

5. Pedro-Carroll, J. Putting children first: Proven parenting strategies for helping children thrive through a divorce. J Marriage Family 2010;48:2-13.

6. Claiborne S. Available from: http://www.gospelhour.net/titles.htm; http://www.gospelhour.net/titles.htm. [Last accessed on 2019 Sep 11].

7. Cathy J. Consequence of Divorce on Children's Life and Adjustmen Period; 2013.

8. Woldekidan K. Child Trafficking and Child Migration in Bahir-Dar the Cases of Child Sex Works, Child Domestic Servants, and Street Forum on Street Children-Ethiopia; 2003.

9. Abebe YM. Lived experience of divorced women in Ethiopia. J Polit Sci Dev 2015;3:268-81.

10. Shibeshi A. Causes of Divorce and its Consequences on Children. Addis Ababa, Ethiopia: A Master Thesis; 2015.

11. Wendie Y, Seid J. Psycho-social and economic consequences of divorce in Muslim community. Innovare J Soc Sci 2014;2:51-7.

12. Wendie Y, Seid J. Determinants of divorce in muslim community. Innovar J Soc Sci 2016;4:6-11.

13. United States Agency for International Development. Performance Monitoring and Evaluation Tips: Conducting Focus Group Interviews. Washington, DC: United States Agency for International Development; 2011.

14. Creswell JW. Qualitative Inquiry and Research Design. Thousand Oaks, CA: SAGE Publications; 2014.

15. Ebenezer A, Lawuo HJ. Uncovered coping strategies adopted by children living in homes with parental divorce for their own survival. J Educ Pract 2015;6:114-28.

16. Genemo MG. The causes, consequences and coping strategies of Streetism in Shashemane town. Int J Psychol Brain Sci 2018;3:40-54.

17. Akhtar E. Social and economic problems of divorced women. Res Hum Soc Sci 2016;6:2224-5766.

18. Parks AB. The Effects of Family Structure on Juvinile Delinquency. Journal of Electronic These and Dessertation, December; 2013. p. 2279-87 